\title{
CONSIDERAÇÕES SOBRE A RELAÇÃO ENTRE RELIGIÃO E MAGIA NO SENSO RELIGIOSO CONTEMPORÂNEO
}

\author{
CONSIDERATIONS ON THE RELATIONSHIP BETWEEN RELIGION AND MAGIC
}

IN THE CONTEMPORARY RELIGIOUS SENSE

TAtiane APAREcida De Almeida ${ }^{(*)}$

\begin{abstract}
RESUMO
O presente artigo tem por objetivo apresentar considerações teóricas acerca da relação entre religião e magia no senso religioso contemporâneo. Nessa perspectiva, destaca-se essa relação como um aspecto já existente desde os primórdios da sociedade dita primitiva, conforme o sociólogo Marcel Mauss apontou na obra Esboço de uma teoria geral da magia. No primeiro momento será abordada a compreensão acerca do senso religioso contemporâneo, para posteriormente se tratar do senso religioso em transformação a partir da relação entre religião e magia e, por fim, apresentar os impactos dessa relação no senso religioso contemporâneo.
\end{abstract}

Palavras-ChaVE: Senso religioso contemporâneo. Magia. Religião.

\section{ABSTRACT}

The present article aims to present theoretical considerations about the relationship between religion and magic in the contemporary religious sense. From this perspective, we emphasize this relationship as an aspect that had existed from the beginnings of the so-called primitive society, according to what sociologist Marcel Mauss pointed out in the work "Sketch of a general theory of magic". In the first moment we will approach our understanding of the contemporary religious sense, to later approach the religious sense um transformation from the relation between religion e magic, then finally to present the impacts of this relation in the comtemporary religious sense.

KEYWORDS: Contemporary religious sense. Religion. Magic.

\section{INTRODUÇÃO}

Este artigo é fruto das discussões realizadas no cenário do Grupo de pesquisa Religião e Cultura, vinculado ao Programa de Pós-Graduação em Ciências da Religião da PUC Minas, coordenado pelo professor Dr. Flávio Senra. O Grupo é constituído por orientandos (as) do docente e tem como proposta a investigação do senso religioso contemporâneo.

Conforme apresentação da temática realizada pelo coordenador do grupo ao CNPq ${ }^{1}$, o objetivo de tal discussão é dedicar-se ao estudo do senso religioso em transformação. Neste sentido, são apontados diversos caminhos para se pensar tal fenômeno na contemporaneidade. Dentre eles está o niilismo, o processo de secularização, a individualização da crença e a desinstitucionalização da experiência religiosa. Destarte, também interessa ao Grupo o estudo dos Novos

(*) Mestra em Ciências da Religião pela Pontifícia Universidade Católica de Minas Gerais (PUC Minas). Email: tatyanealmeida-10@hotmail.com.

${ }^{1}$ Informações coletadas no Diretório dos Grupos de Pesquisa na Plataforma Brasil Lattes. O endereço para acessar o espelho do Grupo de pesquisa Religião e Cultura é: <dgp.cnpq.br/dgp/espelhogrupo/o30987796 $4508266>$. 
Movimentos Religiosos, de grupos e indivíduos que se declaram sem religião, a existência de espiritualidades laicas e espiritualidades alternativas.

Portanto, são várias as vertentes desta discussão, sendo importante ressaltar a possibilidade que ocorram desdobramentos dos temas num futuro próximo, devido às constantes transformações do religioso na sociedade contemporânea.

Nessa perspectiva, destacamos o estudo da magia como um aspecto a ser pesquisado, não como um novo elemento que emerge, mas sim como um elemento já existente no seio da sociedade contemporânea, conforme Marcel Mauss (2003) apontou em seu estudo. Ainda assim, não é objetivo ignorar o momento no qual ele concebe sua obra. A novidade está em apreciar tal teoria através das lentes de uma sociedade na qual diversos fenômenos emergem, ao mesmo tempo em que o fenômeno da religião se mostra em transformação.

Em síntese, esse artigo tem por objetivo trazer contribuições no que tange às transformações do cenário religioso contemporâneo sob a ótica da relação entre religião e magia. Para tal, foi realizada uma pesquisa teórica de natureza básica, tendo em vista a fundamentação do referencial teórico.

Ademais, em um primeiro momento sublinha-se o que se compreendeu por senso religioso contemporâneo a partir das ideias levantadas no Grupo de pesquisa Religião e Cultura. No segundo momento retomam-se as discussões que apontam para o senso religioso em transformação a partir da relação entre religião e magia. Por fim, o artigo será conduzido no intuito de evidenciar de que maneira a relação religião e magia se reflete como uma das características do senso religioso contemporâneo.

\section{DEFINIÇÃO DE SENSO RELIGIOSO CONTEMPORÂNEO}

Entende-se por senso religioso a dimensão pessoal e coletiva do indivíduo, cuja sensibilidade se expressa em relação à dimensão espiritual, que apesar de sofrer alterações de tempos em tempos, é sempre contemporânea. Nessa vertente, o tempo e o espaço em que o sujeito se estabelece surgem como aspectos norteadores, mediante os quais as características da sociedade em que o indivíduo se estabelece podem interferir. Portanto, a sociedade remete o sujeito à essência daquilo que a cultura expressa por religião. Ribeiro e Campos, precursores na discussão da temática, manifestam o entendimento de que

[...] o senso religioso se refere ao sentimento, às disposições, aos movimentos e manifestações daquilo que as pessoas e grupos expressam em relação à dimensão espiritual, ou seja, ao ultrapassamento qualitativamente superior aos anseios ordinários e rotineiros. (RIBEIRO; CAMPOS, 2014, p. 314). 
Ou seja, o senso religioso está intimamente ligado à maneira do indivíduo viver a sua espiritualidade. Logo, tem-se a liberdade do não acolhimento da institucionalização, que é, em suma, a premissa daquilo que é caracterizado por religião. Nessa perspectiva, a sociedade, em sua notável força moral, se debruça sobre a organização da religião, tida até então como classificatória, que demanda diversos agrupamentos ${ }^{2}$ a título de simples arranjo.

O senso religioso contemporâneo revela um momento cujas questões se mostram próximas do indivíduo, de forma mais íntima da sua subjetividade, a partir das configurações pelas quais passa a modernidade. Nesse caso, as questões que fazem interface com o religioso, são, em tudo, expressões que se destacam na contemporaneidade, cujas questões expressam o caráter individual do ser humano.

Tendo como base os diversos temas correlacionados à contemporaneidade, vale destacar, mesmo que de forma sucinta, os fenômenos da emoção religiosa e da secularização, na intenção de demonstrar e ilustrar sua pertinência no cenário contemporâneo no que diz respeito ao indivíduo. Foram escolhidas essas duas categorias por se tratarem de temas já visitados ${ }^{3}$ durante a trajetória desta acadêmica, cujo enfoque trouxe a reflexão aqui apresentada como indícios da reconfiguração da religião na contemporaneidade.

O primeiro tema a ser discutido é o da emoção religiosa, o que para Velho (1991) está atrelado à crença. Isto quer dizer que, segundo Velho (1991, p. 123), o sistema cognitivo - que rege a noção de crença - mostra-se intimamente associado à emoção e isso implica, de imediato, o sentimento do indivíduo. Portanto, a sensibilidade do indivíduo frente à crença se potencializa e aflora, a fim de abarcar um grande montante de pessoas dispostas a compartilhar a crença em prol de uma afirmação do sentimento de coletividade.

Danièle Hervieu-Léger (2008, p. 65-80), cuja discussão é pautada a partir dos novos movimentos religiosos, salienta como as comunidades caracterizadas pela valorização da relação emocional - relação essa que é praticada entre os fiéis e a instituição religiosa -, propiciam o sentimento do "nós". Vale destacar que Hervieu-Léger desenvolveu na obra $O$ peregrino e o convertido um esquema, a partir de quatro lógicas, para tratar do processo de identificação religiosa nas sociedades atuais. As quatro lógicas apresentadas pela autora são: 1) lógica comunitária: delimitação social do grupo e definição formal do grupo quanto a adesões; 2) lógica ética: introduz valores compartilhados e normas de comportamento; 3) lógica cultural: reúne saberes que constituem a memória

${ }^{2}$ Vale sinalizar as especificidades desses grupos e, claro, de forma particular, a de seus indivíduos, dentro dessa conjuntura operante que é a sociedade.

3 Ver Almeida; Moura (2014) e Ribeiro; Almeida; Moura (2015). 
comum do grupo. 4) lógica emocional: diz respeito à experiência afetiva associada à identificação e implica no sentimento coletivo de pertença.

A discussão está pautada a partir da identidade religiosa, que pode ser interpretada por duas vias: a primeira caracteriza-se por ser individual e a segunda, por ser coletiva. Porém, ambas se articulam dentro das quatro lógicas caracterizadas pela autora. As lógicas funcionam de acordo com tensões, duas a duas. Desse modo, o primeiro eixo articula a tensão entre a lógica comunitária e a ética. O papel dessa tensão é manter o equilíbrio da autonomia entre as identificações, propiciando que a consciência do sujeito crente seja valorizada sem perder a identidade de uma linhagem de fé. A segunda tensão está no âmbito da lógica emocional e cultural, que garante a socialização dos indivíduos, considerando seu sistema cultural através de um esquema regulado e de continuidade no tempo e no espaço. Entretanto, tratam-se também das experiências legitimadoras da memória autorizada da tradição ou, também, lida como a manutenção do poder religioso, uma vez que a emoção religiosa está associada à identificação - individual e coletiva - com o papel preponderante para se atingir a experiência religiosa.

Para Hervieu-Léger, a função da memória4 ${ }^{4}$ religiosa está em resgatar uma descendência de fé. Isto é, a religiosidade emocional está ambientada no universo da memória, a fim de oferecer ao indivíduo uma identidade. Afinal, "toda religião implica em uma mobilização específica da memória coletiva." (HERVIEU-LÉGER, 2005, p. 87). E essa memória, por estar todo tempo ativa, deve estar também direcionada à atividade de resgatar a descendência da fé. Vale ressaltar que, especialmente na sociedade contemporânea, existe a presunção de uma memória única; portanto, é possível pertencer a vários grupos.

Camurça (2011) identifica ser esse o fio condutor do estudo da memória, da transmissão e da emoção em Hervieu-Léger, uma vez que, para a socióloga, "a religião se define por meio da transmissão e perpetuação da memória de um acontecimento fundador original através de uma 'linhagem religiosa' ou 'linha de crença'.5" (CAMURÇA, 2011, p. 251). Ou seja, as transformações ocorridas na sociedade interferem de forma plena nos assuntos religiosos. Camurça (2011, p. 252) aponta para um processo de "mascaramento" que ocorre nas tradições religiosas, cujo sentido está em camuflar as mudanças que nelas ocorrem, para assegurar o seu caráter tradicional. Logo, o modo como a religião se apresenta

4 Ver Halbwachs (1990), Barrozo (2014) e Rivera (2000).

5 Segundo Camurça (2011, p. 251), a crença religiosa em Hervieu-Léger está associada à linha crente, que é um elemento legitimador do processo de conservação e perpetuação da religião, ou seja, da memória religiosa. Trata-se de uma "crença específica na continuidade da linha crente". 
na vida do sujeito corresponde ao modo em que a sociedade a incorporou enquanto cultura.

Uma das formas de expressão da sociedade através da religião está na forte valorização das emoções que, quando articuladas aos ritos, se sobressaem a partir da subjetivação da crença. Tal expressão é propícia para o surgimento de "comunidades emocionais"6 no bojo da sociedade que, após serem engendradas na coletividade, irão favorecer que o vínculo religioso se fortaleça ou até mesmo se crie. Hervieu-Léger (1997, p. 43) acredita que o fator emocional é um dos relevantes aspectos que trazem a secularização à tona, acarretando, então, a segunda perspectiva desse ensaio.

Também estudiosa do fenômeno da secularização, Hervieu-Léger parte do estudo da religiosidade moderna, defende a ideia de que a secularização está totalmente ligada à modernidade no sentido de acarretar alterações no religioso e na religião. Destarte, a conceituação por parte de Hervieu-Léger (2008, p. 37) aponta em direção ao movimento de busca da sociedade por sua autonomia religiosa, a partir da perda da influência do sistema religioso.

Portanto, nessa abordagem, o fenômeno da secularização não significa o fim da religião, mas, sim, uma nova reconfiguração, em que o sujeito se mostra capaz de orientar a si mesmo e seu destino, em todas as vias que garantem a sua existência. Tal fato se deve às transformações que aconteceram na modernidade e que acarretaram esse movimento. Em especial, Hervieu-Léger (2008, p. 57) destaca a crise na transmissão da memória, cujo sentido está na perpetuação da religiosidade.

Em meio a isso, Hervieu-Léger (2008, p. 31-33) salienta três características da modernidade, que colaboraram para o enfraquecimento da religião. A primeira característica faz menção à racionalidade, cujo sentido está nas relações sociais e na necessidade de explorar o pensamento científico. A segunda, denominada de autonomia do sujeito, apresenta a ideia de que o sujeito constrói sua autonomia, dia após dia, dentro do sistema da modernidade até o momento em que concebe sentido à sua existência, de forma a conceber seu próprio mundo. Por fim, a terceira, a organização social, que discute a separação entre Igreja e Estado, em que a premissa está na autonomia da instituição, também entendida como o processo de laicização da sociedade. Todavia, vale ressaltar que a autora escreve num contexto francês.

É possível perceber o caráter moderno engendrado nas concepções religiosas, fortemente atrelado ao movimento de autonomia do indivíduo que,

${ }^{6}$ Segundo Moraes e Abumanssur (2007), tratam-se de grupos marcados pelo emocionalismo, nos quais as experiências individual e emocional produzem as chamadas comunidades emocionais. Todavia, para Hervieu-Léger (1997), os novos movimentos religiosos são a expressão dessa adesão pessoal em decorrência dos laços afetivos. 
através de suas próprias compreensões, pode escolher ou não uma forma religiosa. Portanto, "o religioso no mundo contemporâneo parece diferir substancialmente das religiões que estruturavam o universo institucional e simbólico das sociedades ditas tradicionais." (RANQUETAT JÚNIOR, 2009, p. 108). Assim, com a modernidade, as demandas individuais - que é uma das características da magia - acentuam-se na religião como ponto crucial. $\mathrm{O}$ individualismo religioso configura-se também enquanto ações pessoais dos indivíduos que influenciam o tecido social contemporâneo. Diante disso, o

[...] senso religioso, embora constitutivo do ser humano enquanto disposição para um ultrapassamento de seus limites está sempre determinado pelo caráter de temporalidade, ou seja, de uma contextualidade epocal. (RIBEIRO; CAMPOS, 2014, p. 314).

Nessa vertente, Agamben (2009, p. 58), ao discutir o que é contemporâneo, faz menção a Nietzsche, que relaciona a contemporaneidade a algo intempestivo, isto é, a algo que se produz em um momento importuno, numa espécie de rompante que interfere de forma contínua nas questões que dizem respeito à sociedade.

A ideia é que, a partir de transformações e do surgimento de novos fenômenos históricos e culturais no âmbito da sociedade, a sensibilidade humana acompanhe esta transformação ou se perderá no tempo. Uma vez que a religião é um dos diversos fragmentos culturais do indivíduo, e esse elemento é também um produto da construção coletiva que em cada sociedade se mostra com características próprias, conclui-se que "se a sociedade evolui e se transforma historicamente, o mesmo deve acontecer com o componente religioso." (GUERRIERO, 2012, p. 19-20).

Por exemplo, vale refletir que, nos primórdios do pensamento religioso, graças, milagres, previsões, também eram o que se buscava de xamãs e feiticeiros. No senso religioso contemporâneo, o fenômeno da magia atrelado ao íntimo contato entre religião e magia, aponta para a reconfiguração dos agentes religiosos. É plausível pensar que houve uma apropriação do simbolismo entre os grupos - magos e religiosos. Houve, de fato, uma transformação; contudo, a cultura não se perdeu na essência, sobretudo a religião revela não ter perdido seu íntimo contato com a magia na contemporaneidade.

Diante de uma nova configuração da crença, especificamente marcada pelas características da modernidade, vem à tona a necessidade do indivíduo, que está muito mais voltado à procura de uma mensagem do que à adesão a uma instituição religiosa, ou seja, é uma relação que se irradia na forma coletiva para se consolidar na forma particular. 
Com base nisso, "é a ação que domina a vida religiosa pelo simples fato de que ela tem por fonte a sociedade." (DURKHEIM, 2008, p. 495). Ou seja, dentro desse contexto, as ações religiosas e mágicas tendem a se misturar e se externar no social também a partir das emoções em um sistema de complementaridade.

Dito isso, a caracterização do senso religioso contemporâneo aqui proposta constitui um primeiro e consciente passo, com o intuito de abrir caminhos para reflexões mais maduras, num futuro próximo, visto que ainda há um vasto caminho a se percorrer rumo ao entendimento entre sociedade, indivíduo e religião. Com relação ao próximo tópico, o objetivo está em discutir o senso religioso contemporâneo atrelado aos fenômenos da magia e da religião.

O SENSO RELIGIOSO EM TRANSFORMAÇÃO A PARTIR DA RELAÇÃO ENTRE RELIGIÃO E MAGIA

Na contemporaneidade, são recorrentes os casos de líderes religiosos que não passam por uma formação institucional, mas foram designados a esses cargos por aptidão. Ao mesmo passo que os magos são moldados a partir da crença que o indivíduo a ele devota e a partir do espaço privilegiado que a comunidade reserva ao agente da magia, o agente religioso também percorre esse mesmo caminho, rumo à aprovação e aceitação do público.

O mago contemporâneo revela-se uma espécie de mentor religioso dos fiéis, o ser capaz de provocar transformações na vida de quem recorre à magia por meio do sobrenatural. Além do papel de mago, o agente religioso tende também a desempenhar diversos papéis, dentre eles, o de psicólogo, político, e até mesmo médico, através do poder expresso pelo seu status religioso.

Falar de religião no senso religioso contemporâneo, marcado pela crise do fenômeno religioso, implica falar também de uma reconfiguração da instituição religiosa e de seus líderes.

A reconfiguração da crença pode ser interpretada como o cerne do movimento pelo qual o indivíduo contemporâneo trouxe à modernidade o caráter individual da religião, já que "nas sociedades modernas, a crença e a participação religiosa são assunto de opção pessoal” (HERVIEU-LÉGER, 2008, p.34). Destarte, a sensibilidade do ser humano se expressa na dimensão espiritual ancorada na característica do individualismo.

Segundo Steil (2001, p. 117), tantas transformações no campo religioso, particularmente no brasileiro, propiciaram o surgimento de novas formas de expressão do religioso ao mesmo tempo em que as religiões tradicionais perderam sua hegemonia. Tomando essa afirmação como referência, conclui-se que tais mudanças também colaboraram para que muitas manifestações 
religiosas pudessem sair de seus esconderijos obscuros e constantemente julgados; nota-se, aí, a magia.

Nesse sentido, acreditamos que a tolerância religiosa que caracteriza a sociedade moderna também está permitindo uma revitalização de rituais e crenças tradicionais e/ou individualizadas, que eram abafados pelo sistema dominante. (STEIL, 2001, p. 117).

A autonomia do indivíduo tem apresentado uma importante chave de leitura para se pensar a modernidade. Torna-se ostensiva a autonomia do sujeito na contemporaneidade, evidenciada pelos dados apresentados a cada 10 anos pelo Censo do IBGE. Por exemplo, dentre outras observações, o último censo evidenciou um alarmante trânsito religioso e o crescimento dos sem-religião.

Ao pensar sobre o Censo do IBGE 2010, Amaral (2013, p. 297) defende a ideia de uma cultura religiosa que seja reflexo da ação autônoma do indivíduo dentro e fora do campo religioso, um campo de experimentações de caráter subjetivo que perpassa o institucional, isto é, uma ação autônoma na ordem coletiva. Evidencia também que as estatísticas do Censo 2010 fazem fronteiras com o contexto da modernidade, que se caracteriza enquanto

[...] uma movimentação que aponta para uma tendência da religião em se tornar um amplo leque de recursos culturais, disponível para a experimentação de indivíduos autônomos que operam independentemente de sua instituição ou preceitos universais. (AMARAL, 2013, p. 297).

É plausível pensar, mesmo que hipoteticamente, numa crise das instituições religiosas, particularmente se observarmos o crescente número de pessoas declaradas sem-religião e do importante e justo crescimento da diversidade dos grupos religiosos do Brasil, fato esse que, conforme Amaral (2013, p.306) foi obtido através da avaliação dos formuladores do Censo 2010. Ao abordar o tema "uma cultura religiosa errante", Amaral (2013, p. 306) trata da "suspensão dos comprometimentos identitários que possam se apresentar como um obstáculo para a experimentação do sentido". Nessa interpretação de Amaral, fica claro que o indivíduo não se utiliza de intermediários; o próprio sujeito, a partir da suspensão do juízo de valor, permite-se ou até mesmo especula outras crenças, de maneira menos próxima. Ou seja, onde há oferta, há procura - as instituições religiosas que na modernidade alimentam o indivíduo a partir daquilo que ele opta em consumir, sejam rituais ou bens religiosos, seja de forma presencial ou através das mídias.

Frente a isso, Amaral (2013) destaca que a partir da contribuição de Marcel Gauchet, que defende em suas obras a ideia da saída da religião, foi possível chegar a essa conclusão. Contudo, é importante sinalizar que Gauchet defende a 
ideia de que a pluralidade também possa ser entendida como uma das características da saída da religião. Lott (2014, p. 20) 7, estudioso de Gauchet, afirma que o filósofo francês define "as crenças contemporâneas como religiosidades ou espiritualidades no contexto da saída da religião e não como religiões no sentido estrito do termo." O que muito corrobora para esse posicionamento é a importante e necessária conquista da laicidade do Estado 8 que, numa visão gauchetiana, se estabelece na França. Posto isso, a laicidade, nesse contexto, se mostra de forma avançada nas operações políticas e participa de forma ativa do desdobramento histórico, o que muito contribui para se entender o estado atual da religião na contemporaneidade, marcada, sobretudo pela ascensão do indivíduo.

Logo, a autonomia moderna, associada à ideia de que o homem é um ser social, produz no sujeito moderno a capacidade de reger a própria lei, ou seja, a própria vida. Isto é, ao entender-se como dono de si, o indivíduo desprende-se da tradição religiosa que o designa, de forma a afirmar sua subjetivação, indo, por fim, para fora da religião. O movimento que o indivíduo moderno faz, nesse contexto, é o de se apropriar de forma autônoma da ordem coletiva, ou seja, passa a ter plena posse de si e do meio em que vive, sendo o único responsável pelas suas escolhas, especialmente as de origem religiosa.

Nesse momento, a escolha individualizada exerce papel decisório na pertença religiosa, pois, através da autonomia da democracia moderna, a emancipação do político passa a ser entendida como perfil decisório para a nova situação entre política, religião e indivíduo. De acordo com Lott,

[...] a lógica da democracia moderna segue uma dinâmica que provocará uma ruptura revolucionária. Para o filósofo francês, é a dinâmica da individualização que impulsiona esse movimento e faz surgir a figura do indivíduo que encarna a autonomia. (LOTT, 2014, p. 27).

A partir do momento em que o indivíduo se tornou autônomo, ele também se envolveu num movimento emancipatório que "permitiu o reencontro da humanidade consigo mesma, pois converteu o direito de Deus em direito dos homens.” (LOTT, 2014, p.31). Trata-se de um movimento que representa a

70 professor Henrique Marques Lott é integrante do Grupo de pesquisa Religião e Cultura desde o ano de 2015. Nesse ano, iniciou seu estágio pós-doutoral (bolsista PNPD CAPES), sob a supervisão do Prof. Flávio Senra. No segundo semestre de 2016, ministrou, nas dependências do Programa de Pós-Graduação em Ciências da Religião da Pontifícia Universidade Católica de Minas Gerais, o Workshop intitulado A saída da religião e antropossociologia transcendental de Marcel Gauchet, no qual apresentou, em cinco seções, as principais reflexões sobre a religião desenvolvidas pelo autor francês, que perpassam os temas: religião, política, transformações sociais, o cristianismo como a religião de saída da religião, heteronomia, autonomia e democracia na perspectiva do religioso após a religião. Ver: Religião, Política e Democracia A Sociedade Desencantada de Marcel Gauchet, 2016.

${ }^{8}$ Segundo Horácio (2010, p. 132), para Gauchet, “o surgimento do Estado é o principal processo que levará a substituição da religião de seu estado 'mais puro' ao consequente 'desencantamento do mundo'”. 
emergência dos indivíduos que requerem para si o controle das instituições que se organizam no seio da sociedade, e isso não é de exclusividade da religião.

O indivíduo exprime, a partir de tantas mutações e através da sua cultura, o seu novo modelo de sociedade. Uma sociedade liberta e disponível a novas experiências e que seja capaz de desempenhar controle sobre as diversas instituições que se constituem no seu bojo.

Mesmo em volta a tanto subjetivismo, a religião ainda conserva uma série de ritos, símbolos e significados que agem a partir da coletividade, mesmo sendo efetuados e alicerçados na individualidade do sujeito, assim prevalecendo a ideia de comunidade.

Segue, a título de exemplo, uma memória da pesquisa Senso religioso e contemporaneidade (FIP PUC Minas 2013-2014), realizada em conjunto com Cassiana Matos de Moura e que culminou no trabalho de conclusão do curso de Pedagogia com aprofundamento em Ensino Religioso da autora desse texto. Nessa pesquisa, descreve-se uma pequena passagem de um culto na Igreja Mundial do Poder de Deus, no bairro Capelinha/Betim-MG.

Para contextualizar, nesse culto se apresentou a campanha da rosa. $O$ pastor distribuiu aos fiéis uma rosa de plástico, para que a levassem para casa com a seguinte finalidade - explicou o pastor:

Esta é uma rosa sagrada, esta rosa vocês levarão para casa e ela sugará todas as impurezas, tribulações, doenças, qualquer problema que vocês estiverem passando. A campanha vai durar quatro semanas, durante essas quatro semanas vocês levarão esta rosa para casa e todos os domingos vocês vão trazer ela para eu ungir. No quarto domingo, ao final do culto, eu vou recolher a rosa e levar para o monte para queimar, mas não irei queimar em qualquer fogo, queimarei as rosas num fogo santo, no fogo do inferno. (Pastor) ${ }^{9}$. (ALMEIDA; MOURA, 2014, p. 29).

Ao analisar a fala do pastor, fica evidente que há a apropriação do imaginário que circunda o poder supra-humano. Por sua vez, é importante observar que, desta forma, a magia está relacionada às forças que são imanentes à natureza, ou seja, poderes que podem ser controlados pelo homem. Fica a cargo da religião a veneração das forças que se apresentam de forma transcendente e que, conforme Paula Montero (1986, p. 9), são os poderes superiores aos homens, que controlam e regem a vida humana.

A partir da descrição supramencionada, constatou-se que houve a apropriação de um objeto (rosa) para atender à necessidade subjetiva de cada indivíduo ali presente. A rosa é interpretada como um elemento portador de poder. Através da sacralidade a ela devotada, ela se torna capaz de interpelar

\footnotetext{
9 Material coletado através de observação participante na Igreja Mundial do Poder de Deus, no bairro Capelinha/Betim-MG, no ano de 2014. Ver Almeida e Moura (2014).
} 
toda e qualquer maldição que esteja de alguma forma presente na vida e na casa do fiel. Por fim, o ritual se apresenta como uma espécie de receita: o pastor descreve passo a passo todo o script do rito para o público, que prontamente o atende e se propõe a seguir à risca o rito, tendo convicção de que, caso não siga ou por algum motivo seja interrompido o processo de quatro semanas, todo o ritual perderá sua eficácia. Posto isso, caracterizou-se o ato como mágico, visto que sua tônica é marcada pela repetição, o que também surge como proposta pelo pastor ao propor a repetição do ritual por quatro semanas.

Vale recordar que os atos mágicos se repetem, e é também necessário que haja crença coletiva, ou seja, o grupo tem que acreditar na eficácia do ato. Esse traço também está presente na descrição, e destaca-se a aceitação do grupo em participar da campanha. A crença é coletiva, mas o pedido feito ao pastor, e que se assenta sobre a rosa como portadora de poder é individual e particular. Outro dado importante é o fato de o pastor orientar que o ritual de colher os malefícios seja realizado na casa do fiel, fora da Igreja.

Não é possível deixar de mencionar que a espetacularização entra em cena a cada momento do ato. O contágio emotivo entre os participantes no rito evoca os estados afetivos, que se apresentam como um critério para a autenticidade da experiência espiritual. Logo, "toda essa carga social exercida sobre um dado indivíduo vem acompanhada de estados emocionais e afetivos diversos que causam expectativas e excitações diante das crenças e rituais mágicos." (ANTUNES FILHO, 2012, p.151).

O timbre de voz e a emoção são fatores preponderantes, sobretudo no ritual contemporâneo, o qual assume novas características que, por sua vez, se encontram em diversos aspectos daquilo que Mauss caracterizou por magia.

É possível argumentar que as igrejas na contemporaneidade passaram a ocupar espaços sem planejamento prévio. Desmistifica-se a ideia de uma igreja, por exemplo, quando montes escuros, quase que beirando o ocultismo, são interpretados como espaços religiosos, ainda que o ocultismo tenha sido atribuído, por anos, às atividades maléficas e mágicas.

Os diversos pedidos e as inquietações dos fiéis/clientes, muitas vezes levam as instituições religiosas a classificarem, por dia e hora, os atendimentos que irão propiciar. Desse modo, criam-se as campanhas, por exemplo, a da quartafeira, conhecida no meio pentecostal como o dia do culto de descarrego, ${ }^{10}$ também conhecido por ser o dia de exorcismo, o que, segundo Leite (2010, p.62) representa um ato mágico, uma vez que a magia também desvenda outra,

${ }^{10}$ Leite (2010) realiza uma descrição de um culto de descarrego na Igreja Universal do Reino de Deus. O objetivo do autor foi revelar uma ação mágica que transcorre dentro do universo da IURD, a fim de conter ações maléficas e ajudar pessoas com outros diversos problemas, destacando os de ordem física, psicológica e de saúde. Tal observação foi coletada na Catedral da Fé, em 2009. 
previne contra si mesma e se faz em seguida, tal como se observa na proposta do rito do descarrego.

Entretanto, é possível identificar que tal episódio aconteceu também sob a influência religiosa, ou seja, é clara a percepção do quão essa apropriação do simbolismo, da linguagem e da emoção esteve e está engendrada no imaginário religioso que perpassa a discussão de "fogo santo e fogo do inferno", numa espécie de equivalência. De alguma forma, a rosa, enquanto objeto, foi usada para propiciar a aproximação dos fiéis ao que é almejado por eles, unindo-os de forma coletiva a partir de um demasiado desejo individual. Nessa ocasião, a religião e a magia se mostram como meios facilitadores desse entrelaçamento.

A religião não apenas tem sua origem na sociedade, mas identifica-se com ela. Ou seja, a religião se caracteriza na contemporaneidade a partir dos anseios que a sociedade julga e expressa serem relevantes. Mesclam-se aos resquícios de uma religião os traços de um forte individualismo religioso, em que a magia se acentua por estar em seu habitat natural.

Todavia, o sagrado tem a função de se exercer também de forma coercitiva sobre o indivíduo, assim como a religião; mas, em vista disso, também incorpora o que a sociedade tem na sua essência: ora aspectos sagrados, ora aspectos profanos, e, enfim, ambos se articulam.

Vale ressaltar que, segundo Pierucci (2001, p. 83-86), a magia visa a fins específicos, seus objetivos são bem delimitados e precisos, ao contrário da religião, que é caracterizada por prometer o futuro, a vida eterna e a paz espiritual. Portanto, o indivíduo que almeja um emprego não quer qualquer emprego, ele quer um emprego bom, vai especificamente atrás disso. Logo, a magia não é pensada em longo prazo, ela possui o caráter imediatista e objetivo; por isso, mantém sempre uma receita, uma linha a se seguir durante todo o ritual, cabendo ao indivíduo definir o que se torna sagrado e profano na sua interioridade. Fomentando essa discussão, Pierucci constata que

[...] na "vida real", na ordem dos fatos e não dos conceitos, magia e religião convivem, formam um ecossistema. Mundo afora a magia se forma, se enrama e floresce em ambientes religiosos. Quase por toda parte, o ritual religioso contém componentes religiosos. Quase por toda parte, o ritual religioso contém componentes mágicos evidentes. Existem espaços religiosos que se constituem verdadeiros santuários de magia. Nas mais diferentes religiões, sacerdotes agem às vezes como se fossem magos ou adivinhos, curandeiros ou conjuradores de demônios, e o relacionamento religioso com deuses, santos, almas, anjos e espíritos costuma ter ingredientes mágicos-coercitivos evidentes. (PIERUCCI, 2001, p.99).

Tantos caminhos e atalhos da vida cotidiana acionam mecanismos que têm por finalidade abarcar diversas diferenças. As religiões criam subdivisões dentro 
delas, para não "perderem" seus fiéis para um mundo globalizado e secularizado, no qual impera o fundamentalismo religioso, cuja espiritualidade emerge, ou não, em meio às práticas individuais expressas na vida social.

\section{IMPACTOS DA RELAÇÃO ENTRE RELIGIÃO E MAGIA NO SENSO RELIGIOSO} CONTEMPORÂNEO

As demandas da sociedade são emergentes, os conflitos pessoais minam as relações humanas, o desespero por uma resposta oscila entre o desagregador, mas também como aporte para se fazer novos laços. Contudo, a priori os pares se agrupam de acordo com suas particularidades e por livre e espontânea vontade, fazendo sua própria organização, trazendo também, mesmo que superficialmente no subconsciente, juízos mágicos capazes de enraizar o simbolismo, fortalecer a crença e garantir, através dos desejos e necessidades, a eficácia mágico-religiosa. Posto isso, Amaral (2013, p. 307) identifica que, nesse contexto, a religiosidade contemporânea "encontra no Brasil um terreno cultural místico religioso e mágico propício à sua atualização numa dimensão demasiadamente grande”.

O que muito contribui para esse cenário é a era marcada pela tecnologia, na qual o universo se move a partir de um click. Esse advento tecnológico e midiático também interferiu nos assuntos religiosos. Observam-se instituições que celebram online, velas que se acendem em um clique, estádios que servem de templos, atendimentos religiosos online, enfim, as mídias bombardeiam as televisões e rádios com transmissões sagradas. É verdadeiramente um encantamento camuflado de um “desencantamento", em que a religião se mostra escrava da sociedade.

E um mago nada mais é do que um funcionário da sociedade; o mago se dirige a seu cliente a fim de compreender seus anseios, no tempo e no espaço do cliente. Desse modo, "não pode ser concebido como um indivíduo que age por interesse, a seu favor e por seus próprios meios, mas como uma espécie de funcionário investido, pela sociedade, de uma autoridade na qual ele próprio é obrigado a crer.” (MAUSS, 2008, p.131).

Em consonância, Leite (2010, p. 13-14) traz uma importante informação, ao afirmar que,

[...] com o advento da modernidade e o tão propalado desencantamento do mundo, pudemos perceber uma articulação entre os conhecimentos mágicos ou espirituais com os científicos, através da esperança de uma eficácia ritual necessária. Essa esperança, muitas vezes alimentada pelo desenvolvimento da fantástica indústria de produção de imagem, que, junto com o movimento cultural e histórico da condição humana na atualidade, mergulha no mundo 
místico, valendo-se da magia para tentar atingir o desejável, via o sobrenatural. (LEITE, 2010, p.13-14).

Sendo assim, cabe destacar que a relação do mago com o indivíduo é configurada por uma relação de prestador de serviço e cliente. Contudo, não se faz necessária uma adesão, ser membro de algum grupo, nem sequer é almejada uma relação duradoura entre as partes. Basta haver a necessidade e a crença da eficácia mágica. Na modernidade isso também se faz valer. A manutenção do poder religioso é realizada dia após dia, pois se o culto, ou celebração, não toca o indivíduo, o fiel não possui razões para retornar.

Posto isso, Bauman (2007) ao se debruçar sobre os temas que fazem interface à modernidade, identifica a insegurança como uma das características do ser humano moderno. Logo, a insegurança determina os limites em que vive a sociedade, cujos poderes se chocam com as identidades. Nesse contexto, o desafio do religioso, para manter a autoridade, se relaciona com o cenário de Bauman, uma vez que a emoção trata de acolher e manter, pela via de comunidades emocionais, as religiões, que são, sobretudo, marcadas pela instabilidade, pelo trânsito e pela ausência de memória coletiva. Assegura-se pelo emocional o que não se assegura pelo poder em si, pelo pulso regulamentador que a religião um dia já possuiu. $\mathrm{E}$ os objetos e toda infraestrutura usada nos ritos de vertente mágico-religiosa nada mais são do que tentativas de se despertar a crença do indivíduo, quiçá a fé.

Portanto, ao refletirmos sobre o senso religioso contemporâneo sob a ótica da magia e da religião, percebemos que de fato existe uma relação, embora não seja nova, mas enfatiza-se a partir do sistema de complementaridade.

Não obstante, deve-se pensar que tantas mutações trazem consigo impactos na maneira do crente vivenciar a sua religiosidade e na sociedade que expressa essa cultura. Portanto, vale ressaltar que não é nosso objetivo classificá-los enquanto positivos e/ou negativos, somente apresentá-los de acordo com as percepções alçadas até o presente momento.

Isto é, entre tantas divergências e igualdades, religião e magia se caracterizam por serem considerados fenômenos sociais. Ambos os fenômenos exercem extrema ação na vida individual, a partir da coletividade. A relação entre religião e magia mostra-se impactante na contemporaneidade, uma vez que os preceitos mágicos estão cada vez mais próximos do indivíduo, por conterem em seu mais amplo sentido as questões individuais e a inexistência do vínculo como expressão da ideia de comunidade.

De acordo com Ranquetat Júnior (2009, p. 102), no cenário religioso da "modernidade ocidental, marcada pelo individualismo, as pertenças religiosas se tornam opcionais, o fato de uma pessoa nascer em determinada religião não 
significa que ela professe esta religião por toda sua vida.” Logo, a fluidez do sistema de pertença religiosa, tal como é evidenciada, também promove o trânsito religioso, que surge como um retrato de uma sociedade que se permite experienciar diversas expressões religiosas ao longo de sua existência.

A adesão do fiel ao sistema religioso configura-se pela via de mercado e, nessa busca, o indivíduo se depara com uma diversidade de instituições. Portanto, nesse mercado religioso plural, a necessidade do indivíduo emerge como pré-requisito para a escolha.

Nesse sentido, em qualquer caso em que a instituição não atenda aos anseios do fiel, demonstrando imprecisão, o fiel, personalizado de cliente, muda de agente religioso ou mágico e de espaço para obter uma receita mágico-religiosa que melhor o atenda.

Outra questão que propicia a fluidez da pertença religiosa é o atraente mercado de bens religiosos, em que o fiel pode estar levando para casa seu objeto ou oração e fazer de sua própria casa local de oração e ritual, uma vez que é imensurável o número de santinhos com orações e "receitas" de rituais, simpatias e mantras que são distribuídos em todo o território brasileiro. Ou seja, na contemporaneidade, tantas situações mostram-se cotidianas e próximas do indivíduo.

Posto isso, os preceitos mágicos entrelaçados aos da religião parecem consolidar o processo de individualização da crença que, nesse aspecto, se desenvolve, ao passo que o processo de desinstitucionalização das práticas religiosas emerge. Ou seja, uma religião decaída pode vir a se tornar magia, mesmo que "o enfraquecimento das instituições religiosas tradicionais que ainda intentam trazer o sagrado e seus ritos sobre controle, tenha se desdobrado em várias direções." (VILHENA, 2013, p.523).

Se a magia e a religião de fato sempre possuíram vínculo, como este artigo estabelece esse vínculo, agora se apresenta de forma generalizada, de modo que atribuições dadas somente à magia como, por exemplo, a individualização passa a impactar a religião de forma absolutamente coercitiva. Trata-se de um modelo em que a memória religiosa do grupo religioso também se encontra em crise.

Para Giumbelli (1994, p. 22), a magia se distinguiu por muito tempo da religião, por não formar comunidades morais em relação aos que crêem na magia. Contudo, o modelo de crente mágico-religioso moderno expresso no senso religioso contemporâneo não traz nenhuma garantia de filiação de modo a confirmar a ideia de comunidade; a própria religião pode estar direcionando o fiel a não aderir à religião, sendo este um dado a se pensar enquanto impacto.

Para reflexão, o número dos sem-religião no Brasil, retratado no Censo do IBGE 2010, ocupa o terceiro lugar entre as declarações. O número exato, de 
acordo com Teixeira (2013, p. 27), é de "cerca de 15,3 milhões de pessoas classificadas nessa categoria de sem-religião, ou seja, 8\% da população geral.” Esse dado corrobora a afirmação da existência de uma crise institucional que está impactando a religião. Ou seja, "os declarantes que se encaixam nessa categoria estão mesmo desencaixados de laços institucionais, situando-se, melhor, como peregrinos no sentido." (TEIXEIRA, 2013, p.27).

De fato, o indivíduo precisa sentir-se na religião para que então possa consolidar o processo de identidade com a tradição. A mera vinculação institucional baseada na ideia de comunidade não é mais um dispositivo de segurança ou garantia. O indivíduo precisa expressar e suprir sua subjetividade para se declarar um praticante da religião. Ou então, ele poderá instaurar uma relação mágica, em que o cliente e o mago são unidos pelo laço de necessidade sem perspectiva de adesão, haja vista que após o ritual o mago e o cliente retornam à vida normal, sem demonstrarem indícios de uma relação anterior, sobretudo, sendo essa uma relação da qual se ausenta a memória de fundação da experiência. Dito isso, Hervieu-Léger pondera que

[...] a extrema individualização do crer que caracteriza a paisagem religiosa da modernidade anunciada, o enfraquecimento dos regimes institucionais da validação do crer e a necessidade crescente de confirmação mútua e comunitária das "pequenas verdades" produzidas pelos indivíduos fortalecem consideravelmente o papel de personalidades que podem testemunhar, por sua experiência pessoal, uma precedência no caminho da verdade e, portanto, uma capacidade de iniciar aqueles que estão dispostos a segui-las. (HERVIEU-LÉGER, 2008, p. 164).

No pensamento hervieu-légeriano, os fiéis tendem a se agrupar de acordo com os seus ideais comuns. Uma religião que não legitima a crença tende a se perder no processo de peregrinação, movimento esse que, na obra de HervieuLéger (2008), é calcado na ideia da modernidade.

Esse aspecto faz menção ao indivíduo moderno, que incorpora as exigências do meio em que vive para, enfim, construir suas próprias significações, sendo sua prática peregrina “atestada desde os primórdios". (HERVIEU-LÉGER, 2008, p.87). Isto quer dizer que a ideia de peregrino é anterior à ideia do fiel praticante. Segue, abaixo, a comparação entre peregrino e praticante destacada por Hervieu-Léger;

\begin{tabular}{|l|l|}
\hline A figura do PRATICANTE & A figura do PEREGRINO \\
\hline Prática obrigatória & Prática voluntária \\
\hline Prática regida pela instituição & Prática autônoma \\
\hline
\end{tabular}




\begin{tabular}{|l|l|}
\hline Prática fixa & Prática variável \\
\hline Prática comunitária & Prática individual \\
\hline Prática territorializada (estável) & Prática móvel \\
\hline Prática repetida (ordinária) & Prática excepcional (extraordinária) \\
\hline
\end{tabular}

Fonte: HERVIEU-LÉGER, 2008, p. 98.

Para complementar a explicação, a socióloga menciona os diversos jovens que, advindos de diversas áreas do globo, se encontram para participarem ativamente dos encontros das Jornadas Mundiais da Juventude, organizados pela Igreja Católica, e que se articulam em decorrência da participação do papa em exercício. Contudo, este fato também revela uma possível fragmentação da busca religiosa. Sobre tal empreendimento, Hervieu-Léger (2008) atribui o conceito de bricolagem que, segundo Ranquetat Júnior (2009, p. 101), “é a religião à la carte, onde cada crente constrói seu universo de crenças a partir dos bens simbólicos colocados a disposição pelo mercado religioso.” Isto é, o indivíduo está em busca de sua identidade religiosa baseado nas suas questões subjetivas, o que pode estar associado a essa busca individual por práticas coletivas, como é o caso das Jornadas Mundiais da Juventude. Assim, fica em xeque a adesão total ao sistema, o que corrobora para o surgimento de uma adesão em bloco (HERVIEU-LÉGER, 2008, p. 47).

A ideia de praticante traduz o sentimento de que a religião tradicional espera de seu fiel: uma crença em comunidade, posto que a ideia de peregrino possua laços com o que validaria a relação do mago com o indivíduo e a relação do peregrino com a religião. Pois ambos estão enredados numa relação de mercado, onde há procura e há oferta. Nessa relação de mercado não se faz necessária a adesão a algum grupo religioso. Isso é atestado pela condição da prática voluntária, individual, móvel e autônoma, conforme o quadro de Hervieu-Léger sugere, evidenciando que a vivência religiosa do peregrino o aproxima das condições de um cliente da magia.

Destarte, nesse movimento o indivíduo procura na religião o mesmo que o levaria a recorrer às práticas mágicas, ou seja, um ritual que o auxilie a resolver um problema ou atenda às suas necessidades subjetivas. Afinal, "a situação social que [nós, os indivíduos] ocupamos predestina a exercer a magia e, reciprocamente, o exercício da magia os predestina à sua situação social.” (MAUSS, 2003, p.67). Os indivíduos, através da sua situação social, recorrem aos atos mágicos e se voltam à magia quando percebem que não mais coagem a 
divindade, já que a magia não tem a oração como uma de suas atribuições, mas, antes, caminha sob os princípios do sacrifício ${ }^{11}$.

Em contraponto, numa vertente religiosa, a prática do peregrino, segundo Hervieu-Léger (2008, p. 89), "nem sempre implica a adesão completa a uma doutrina religiosa, tampouco a incorporação definitiva em uma comunidade, sob o controle de uma instituição que fixa as condições da pertença." Novamente, a ideia de uma religião marcada pelo trânsito religioso, caracterizado pela mobilidade, torna-se um fator comum que favorece o que Hervieu-Léger denomina por prática excepcional ou extraordinária. Dentre tantas transformações, considera-se o enfraquecimento das instituições religiosas tradicionais, que se mostram impactadas pelo sucesso do indivíduo a reger o seu próprio destino. Segundo Barrozo,

[...] o declínio do fiel praticante não seria apenas uma realidade restrita ao catolicismo, mas se colocaria como tendência também para outras tradições religiosas. É justamente esse modelo do fiel praticante, que articula crença e pertença como forma cristalizada de ideal religioso, que Hervieu-Léger julga estar em cheque, visto os movimentos de desregulação dos meios de transmissão religiosa, enfraquecimento institucional, individualização do crer, mobilidade de pertenças - características já sublinhadas da modernidade religiosa. (BARROZO, 2014, p. 39).

Nesse contexto, o declínio do fiel praticante é expresso, ao passo que a secularização se estabelece enquanto fenômeno de destaque, favorecendo a perda do monopólio das instituições tradicionais e a reconfiguração do sistema religioso. A mobilidade do fiel praticante marcou o período de total instabilidade das adesões religiosas, mas também favoreceu o surgimento das comunidades emocionais na contemporaneidade. Sobre isso, Mauss (2003, p.169) chegou a cogitar que os preceitos emocionais eram um ponto de encontro entre religião e magia, afirmando:

Reservamos para um outro momento demonstrar que ambas [religião e magia] vêm de uma fonte comum. E, se fizemos ver pelo estudo desses fatos que a magia saiu de estados afetivos sociais, não nos desagrada ter consolidado, ao mesmo tempo, a hipótese que já havíamos feito para a religião. (MAUSS, 2003, p. 169).

Logo, os estados emocionais favorecem a realização pessoal do indivíduo, bem como resultam nas atividades do êxtase e do transe, pontos característicos da magia e que hoje se acentuam no universo religioso. Considera-se que "as entidades, nas religiões de transe, mediunidade, possessão, possivelmente

\footnotetext{
${ }^{11} \mathrm{Na}$ obra Ensaio sobre a dádiva: forma e razão da troca nas sociedades arcaicas, Marcel Mauss aponta que o sistema de troca entre o homem e os deuses é um aspecto da teoria do sacrifício.
} 
funcionam como mediadores neste processo de individualização/desindividualização.” (VELHO, 1991, p.128).

Posto isso, as comunidades emocionais fazem interface a essa questão no sentido de que as subjetividades emergem a partir de conflitos individuais que desempenham forte aparato emocional no indivíduo. $\mathrm{E}$ isso ocorre numa era em que, segundo Leite (2010, p. 106), "a experiência mágica, especialmente como manipulação da realidade, tem sido objeto de procura nas sociedades contemporâneas pela situação de incerteza e mal estar próprios do mundo moderno.” Logo, a magia é percebida como um anestesiador da mente humana, uma ação capaz de transformar seja um estado emocional, seja uma realidade objetiva configurada por um dado momento. Ela é entendida, pois, como a garantia de que tudo irá transcorrer bem.

Em particular, Birman (1993, p. 44) chama a atenção para o crescente consumo de livros de autoajuda na contemporaneidade, especialmente no Rio de Janeiro. Trata-se de obras direcionadas para um público seleto, cujos temas estão voltados a atender determinados grupos de pessoas em cujo íntimo tem repousado algum desgosto. Esses temas podem transitar entre todas as perspectivas que garantem o bem-estar, podendo ser lidos sob diversas lentes que envolvem as particularidades nas relações pessoais de forma geral. Nesse sentido, "a utilização da magia permite, através da experiência, ter acesso a uma 'verdade' numa dimensão alternativa da realidade social, manipulável de acordo com os desejos e anseios individuais e que, ao mesmo tempo, são coletivos." (LEITE, 2010, p. 106).

Desse modo, o livro de autoajuda tende a prestar a esse indivíduo uma espécie de consultoria. Segundo Birman (1993, p. 45), especialmente nesse tipo de literatura está presente a busca por legitimidade científica e a relação do indivíduo com espíritos, de modo que se utiliza da premissa de se apresentar enquanto elemento norteador que favorecerá para que o indivíduo possa conviver melhor consigo mesmo e com todo o porvir. Para Birman,

[...] a dignidade conferida ao pensamento mágico, longe de significar um retorno a modos tradicionais de pensar, parece-nos indicar o seu oposto - a crença na magia, pedagogicamente proposta, está associada a uma representação da vida social claramente moderna e desencantada: preside a esta representação a ideia de que o mundo em que vivemos é engendrado por nós - é efeito de uma construção que nos tem como seus atores em todos os momentos. (BIRMAN, 1993, p. 45).

Tais livros têm como premissa capacitar o indivíduo para que ele possa, por si mesmo, construir suas significações. A linguagem neles presente muitas vezes é de fácil compreensão e utiliza-se de esquemas, como uma espécie de receita, 
pois, seguindo-a, ao término o leitor poderá se sentir investido da ideia da eficácia.

Birman (1993, p.49) chama a atenção para as propostas individuais que fazem pano de fundo a essas obras. Elas visam à luta contra forças negativas e têm em sua base a proposta de uma limpeza mental e um ajustamento do indivíduo ante as inquietações advindas da sociedade, restaurando a ideia de uma guerra espiritual.

Portanto, a utilização da magia nesse espaço vem trazer à tona um sentimento de redenção da mesma. A sociedade que tanto a postulou como falsa, segundo Birman (1993, p. 51), agora cria mecanismos para que a magia saia do espaço obscuro e ocupe a vida pública, veiculada através da cultura, uma vez que tal conteúdo já integra a vida social. Em suas palavras, "vemos esta nova espiritualidade apresentar às consciências tradicionais novos significados para a antiga magia." (BIRMAN, 1993, p. 51). Ou seja, ao passo que a religião se transformou, a magia também se transformou no âmbito da sociedade. $O$ indivíduo carrega consigo desde superstições até receitas de simpatias, e de forma casual dá vida a toda essa imaginação.

Nas últimas linhas de sua obra, Mauss (2003, p. 177) conclui que a magia, em seu estado inicial, desempenhou "a forma primeira de representações coletivas que se tornaram depois os fundamentos do entendimento individual." Ou seja, a magia evoluiu de acordo com as transformações da contemporaneidade. Logo, os impactos aqui interpretados são transformações que, de acordo com o fenômeno da secularização, não irão beneficiar ou acarretar o fim da religião. Contudo, trouxeram um novo sentido ao indivíduo no contexto de uma sociedade globalizada, onde a religião não é mais propriedade do Estado e as práticas mágicas não mais são condenadas.

Neste sentido, as práticas mágicas podem, enfim, sustentar a ideia de que as práticas coletivas são indissociáveis das práticas individuais, especialmente no cenário do senso religioso contemporâneo. A magia é enraizada na perspectiva individual e depende da crença coletiva, ou seja, trata-se indiscutivelmente de um fenômeno social. Este é, pois, o lugar da magia ao lado da religião, lugar esse sobre o qual Marcel Mauss por vezes também se questionou.

No senso religioso contemporâneo, após diversas reconfigurações do crer e do modelo cultural da sociedade, as práticas religiosas assumiram a identidade de uma tradição mágico-religiosa. Isso porque a religião assumiu formas individuais e tantas outras características mágicas, por exemplo, o uso de elementos portadores de poder.

Outrossim, como salienta Steil (2001, p. 124), "não se trata, no entanto, da volta a um sagrado fundante do social, mas de uma recriação de um mundo que, 
embora autônomo em sua base estrutural, está habitado por deuses, forças, energias, mistérios, magias." A ideia de uma religião que preza pela ideia de comunidade não está sendo posta em questão. Contudo, chegou-se ao momento em que as demandas individuais que emergem do sujeito na contemporaneidade realçaram a relação entre religião e magia de forma notória, através da recorrente busca pela manutenção da tradição religiosa, assim como pela busca da instantaneidade, que atravessa o mundo moderno.

Portanto, a relação mágico-religiosa se potencializa enquanto pólo da necessidade à medida que visa atender aos objetivos individuais através de elementos portadores de poder, em tempo hábil e, muitas vezes, sem a necessidade da presença física. Por exemplo,

[...] nos cultos neopentecostais os fiéis são estimulados a fazer seus pedidos em forma de "desafios" ao Senhor. Na missa católica, a transubstanciação do pão em corpo de Cristo é outro exemplo de "magia religiosa". (PIERUCCI, 2001, p.86).

Percebe-se que os ritos fazem uso desses tipos de materiais representativos nas mais diversas religiões: são roupas que representam pessoas, água com a qual se benze, óleo que unge, e assim por diante. Tais rituais, que fazem uso desses materiais, trazem à memória a lei da contiguidade da magia, cujo sentido está na ideia de que uma parte de algo vale pela coisa inteira. No ritual mágico é possível que a roupa passe a representar o indivíduo, criando-se condições para que se possa agir sobre ele. Nesse sentido, também se pode utilizar de objetos, que na perspectiva religiosa são também capazes de simbolizar a figura de um totem que, por sua vez, é capaz de orientar um sentimento e se consolidar enquanto força transformadora.

Steil (2001, p. 124) diz que "a integração da experiência místico-espiritual no universo das práticas identificadas com as novas formas de crer é outro aspecto que tem sido destacado no contexto religioso no final de milênio." Pensou-se, então, em uma possível forma de espiritualidade sem religião, de vertente mística a partir da relação de uma religião secularizada e da magia em ascensão.

$\mathrm{O}$ trânsito religioso, que abole o sistema de adesão religiosa, é garantido a partir da característica individual da magia que, somada à crença coletiva que nutre a religião e magia, faz emergir essa forma de crer, que pode ser interpretada como um tipo de espiritualidade que se tornou de opção pessoal e transitória no senso religioso contemporâneo.

É, portanto, com essa realidade marcada pelas reestruturações na sociedade e nas instituições religiosas que a magia se relaciona com a religião. E isso principalmente a partir do movimento afetivo, que se tornou um dispositivo assegurador das práticas mágico-religiosas. Logo, o divino é manipulado pelo 
homem de acordo com suas necessidades. Mostra-se uma onda de manipulação do divino permeada pela instrumentalização, fator marcante na contemporaneidade, em cujo bojo os ritos são uma forma de suma importância para se desmitificar as práticas que se desenvolvem nos âmbitos religiosos e mágicos.

\section{CONSIDERAÇÕES FINAIS}

Conclui-se que as transformações que ocorreram na sociedade interferiram, de fato, no relacionamento entre o indivíduo, a magia e a religião. Nessa perspectiva, o senso religioso contemporâneo apresenta um cenário mágicoreligioso, em que magia e religião encontram-se entrelaçadas, num sistema de complementaridade, a partir da afirmação da autonomia do sujeito na sociedade, especialmente nas instituições religiosas enquanto fenômenos sociais.

Os elementos da magia - o mago, os atos mágicos e as representações mágicas - defendidos por Marcel Mauss parecem ser usados de forma presente, comum e regular na contemporaneidade, porém com nova roupagem, a roupagem do padre, do pastor e do ritual religioso, defendidos por nós, reconfigurados, que incorporaram as características dos atos mágicos e de suas representações, especialmente pelo caráter individual que irradia da crença advinda da sociedade enquanto fenômeno coletivo.

Isso quer dizer que essa sensibilidade está relacionada à prática do "selfservice" religioso, em que o indivíduo monta seu cardápio de acordo com as ofertas do mercado, construindo a seu modo o mundo religioso que melhor the caiba e que seja capaz de despertá-lo para a participação das práticas religiosas, ou seja, é nesse momento que o senso religioso se expressa. Desse modo, personaliza a sua crença ao seu bel prazer, externando sua sensibilidade espiritual, entendida por senso religioso, seja ela qual for, ultrapassando a ideia de comunidade e abrindo espaço para que floresça o sentimento íntimo do indivíduo, quando posto em confronto com a vida religiosa.

Nesta perspectiva, a magia mostrou-se indissociável das práticas religiosas no senso religioso contemporâneo. Essa relação de complementaridade se faz presente no senso religioso contemporâneo como uma tentativa, por parte da instituição religiosa, de atender às demandas subjetivas de seus fiéis, que anseiam por soluções rápidas e eficazes para seus conflitos vivenciais. Por outro lado, tal relação também emerge como reflexo de uma sociedade que se alimenta de uma religião secularizada, de perfil emocional e que, após a decisiva laicização do Estado, ocupa o papel de um fragmento de cultura. 
Os impactos da relação entre religião e magia na contemporaneidade apresentam uma prática que se confirma enquanto coletiva e pautada na ideia de sagrado, que não se articula somente no ocultismo e é, sobretudo, desmistificada. Trata-se de uma relação que fomenta o trabalho religioso, caracterizado no cenário contemporâneo por mágico-religioso, e que proporciona, através de seus rituais, experiências individuais que ganham sentido na coletividade através do uso contínuo de elementos (objetos ou não) que, no ritual, passam a ser interpretados como portadores de poder.

De acordo com a ideia de secularização, entende-se que a religião, na contemporaneidade, passou por diversas transformações. Nesse contexto, trouxeram à tona os ideais mágicos da vida cotidiana do religioso na contemporaneidade. Tais ideais são, acima de tudo, expressões culturais que ganharam espaço e notoriedade entre as práticas rituais religiosas, saindo da inércia das práticas consideradas obscuras. O mundo contemporâneo parece ter se impregnado de magia, como outrora se impregnou de religião, majoritariamente.

\section{REFERÊNCIAS}

AGAMBEN, Giorgio. O que é contemporâneo? E outros ensaios. Trad. Vinícius Nicastro Honesko. Chapecó: Argos, 2009.

ALMEIDA, Tatiane Aparecida de; MOURA, Cassiana Matos de. A secularização na contemporaneidade: um estudo sobre a perspectiva de Danièle Hervieu-Léger. 2014. (Trabalho de conclusão do curso de Pedagogia com aprofundamento em ensino religioso) - Pontifícia Universidade Católica de Minas Gerais, Departamento de Ciências Humanas, Belo Horizonte.

AMARAL, Leila. Cultura religiosa errante. In: TEIXEIRA, Faustino; MENEZES, Renata (Org.).Religião em movimento: o censo de 2010. Petrópolis: Vozes, 2013, p.295-310.

ANTUNES FILHO, Edemir. A emoção religiosa nos estudos de Émile Durkheim e Marcel Mauss: a propósito do centenário de As formas elementares da vida religiosa”. Estudos de religião, São Bernardo do Campo, v. 26, n. 42, p. 137135, 2012.

BARROZO, Victor Breno Farias. Memória, transmissão e emoção: estudo sobre a modernidade religiosa no pensamento de Danièle Hervieu-Léger. 2014. Dissertação (Mestrado em Ciências da Religião) - Pontifícia Universidade Católica de Minas Gerais, Programa de Pós-Graduação em Ciências da Religião, Belo Horizonte.

BAUMAN, Zygmunt. Tempos líquidos. Trad. Carlos Alberto Medeiros. Rio de Janeiro: Jorge Zahar, 2007. 
BIRMAN, Patrícia. Relativismo mágico e novos estilos de vida. Revista Rio de Janeiro, Rio de Janeiro, v. 1, n. 2, p. 44-52, 1993.

CAMURÇA, Marcelo Ayres. A sociologia da religião de Danièle Hervieu-Léger: entre a memória e a emoção. In: TEIXEIRA, Faustino(Org.).Sociologia da religião: enfoques teóricos. 4. ed. Petrópolis: Vozes, 2011, p. 249-270.

Diretório dos Grupos de pesquisa no portal Brasil Lattes - CNPq.

Disponível em: <dgp.cnpq.br/dgp/espelhogrupo/> . Acesso em: 22 nov. 2016.

DURKHEIM, Émile. As formas elementares da vida religiosa. São Paulo: Paulus, 2008.

GIUMBELI, Emerson. Antropólogos e seus sortilégios: uma releitura do "Esboço de uma teoria da magia" de Mauss e Hubert. Cadernos de Campo, São Paulo, n. 4, p. 21-39, 1994.

GUERRIERO, Silas. A atualidade da teoria da religião de Durkheim e sua aplicabilidade no estudo das novas espiritualidades. Estudos de religião, São Bernardo do Campo, v. 26, n. 42, p. 11-26, 2012.

HALBWACHS, Maurice. A memória coletiva. São Paulo: Vértice, 1990.

HERVIEU-LÉGER, Danièle. Catolicismo: a configuração da memória. Rever, São Paulo, ano 5, n.2, p. 87-107, 2005.

HERVIEU-LÉGER, Danièle. O peregrino e o convertido: a religião em movimento. Petrópolis: Vozes, 2008.

HERVIEU-LÉGER, Danièle. Representam os surtos emocionais contemporâneos o fim da secularização ou fim da religião? Religião e Sociedade, Rio de Janeiro, v. 18, n. 1, p. 31-47, 1997.

HORÁCIO, Heiberle Hirsberg. O fim da alteridade radical e o nascimento do Estado na obra de Marcel Gauchet. Sacrilegens, Juiz de Fora, v. 7, n. 1, p. 132141, 2010.

LEITE, Lucas Farias de Vasconcelos. A dimensão institucional da magia no neopentecostalismo: o papel decisório do poder mágico como atrativo à adesão religiosa na Igreja Universal do Reino de Deus. 2010. Dissertação (Mestrado em Ciências da Religião) - UNICAP, Programa de Pós-Graduação em Ciências da Religião, Recife.

LOTT, Henrique Marques. O limiar entre religião e democracia na obra de Marcel Gauchet. Plura, Juiz de Fora, v. 5, n. 1, p. 19-33, 2014.

MAUSS, Marcel; HUBERT, Henri. Esboço de uma teoria geral da magia. In: MAUSS, Marcel. Sociologia e Antropologia. Trad. Paulo Neves. São Paulo: Cosac Naify, 2003, p. 47-181. 
MONTERO, Paula. Magia e pensamento mágico. São Paulo: Ática, 1986.

MORAES, Gerson Leite de; ABUMANSSUR, Edin Sued. Comunidades emocionais e mídia: uma forma de entender o pentecostalismo brasileiro.

Ciências da Religião: História e Sociedade, São Paulo, v. 5, n. 1, p. 10-33, 2007.

PIERUCCI, Antônio Flávio. A magia. São Paulo: PubliFolha, 2001.

RANQUETAT JUNIOR, Cesar Alberto. Reflexões antropológicas sobre a religião na modernidade. Declínio ou reconfiguração do religioso? Interações:

Cultura e Comunidade, Belo Horizonte, v. 4, n. 5, p. 99-110, 2009.

RIBEIRO, Flávio Augusto Senra; CAMPOS, Fabiano Victor de Oliveira. Senso religioso contemporâneo e os sem religião: uma provocação a partir de Emmanuel Lévinas. Caminhos, Goiânia, v. 12, n. 2, p. 115-129, jul.-dez. 2014.

RIBEIRO, Flávio Augusto Senra; ALMEIDA, Tatiane Aparecida de; MOURA, Cassiana Matos de. Emoção e senso religioso contemporâneo: estudo a partir de Danièle Hervieu-Léger. In: SOTER (Org.). Anais do $28^{\circ}$ Congresso

Internacional da SOTER: religião e espaço público: cenários contemporâneos, Belo Horizonte, 2015, p. 343-350.

RIVERA, Dario Paulo Barrera. Tradição, memória e pós-modernidade. A precariedade da memória religiosa contemporânea. Estudos de Religião, São Bernardo do Campo, v. 14, n. 18, p. 121-144, 2000.

STEIL, Carlos Alberto. Pluralismo, modernidade e tradição: transformações do campo religioso. Ciências Sociais e Religião, Porto Alegre, ano 3, n.c3, p.c115-129, out. 2001.

TEIXEIRA, Faustino Luiz Couto. MENEZES, Renata de Casto (Org.). Religiões em movimento: o censo de 2010. Petrópolis: Vozes, 2013.

VELHO, Gilberto. Indivíduo e religião na cultura brasileira: sistemas cognitivos e sistemas de crença. Novos Estudos, São Paulo, n. 31, p. 121-129, out. 1991.

VILHENA, Maria Angela. Ritos religiosos. In: PASSOS, João Décio; USARSKI, Frank. (Org). Compêndio de Ciência da Religião. São Paulo: Paulinas, 2013, p. 513-524. 